\title{
Strength Evaluation of Soil Subgrade Using In-situ Tests
}

\author{
Daljeet Singh $^{1, *}$, J. N. Jha ${ }^{2}$, K. S. Gill ${ }^{3}$ \\ ${ }^{1}$ Public Works Department, Buildings and Road Branch, India \\ ${ }^{2}$ Government of Bihar, Sitamarhi Institute of Technology, India \\ ${ }^{3}$ Department of Civil Engineering, Guru Nanak Dev Engineering College, India
}

Copyright $\bigcirc 2016$ by authors, all rights reserved. Authors agree that this article remains permanently open access under the terms of the Creative Commons Attribution License 4.0 International License

\begin{abstract}
Flexible pavements in many countries including India are designed on the basis of laboratory California Bearing Ratio (CBR). During construction to ascertain that the design stipulations are met with, one has check in-situ CBR. For testing in-situ CBR, undisturbed samples are taken and are then tested in the laboratory. Collection of undisturbed sample from soil subgrade that is essentially non-plastic in nature, is near to impossible and further more determination of CBR is a time consuming and sensitive to many parameters, such as relative density, particle size, texture, moisture content and confinement pressure etc.. Thus, during execution stage, it becomes very difficult to ascertain whether the design stipulation has been achieved or not. In this study an effort has been made to evaluate the subgrade strength by conducting in-situ tests using Dynamic Cone Penetrometer (DCP) and Light Deflectometer (LWD) on various locations shown in 1), of an under-construction road, that is on the service bank of Sirhind Canal, in Punjab, India. The road is tested at fifteen different locations; representative samples of soil were collected from all the fifteen locations and tested in laboratory for Grain Size Analysis, Atterberg Limits Limit, Plastic Limit), Maximum Dry Density (MDD), Optimum Moisture Content, and Laboratory CBR at 97 percent of modified MDD, to find correlations.
\end{abstract}

Keywords CBR, DCP, LWD, E $\mathrm{mod}_{\text {, }}$ Grain Size and Atterberg Limits

\section{Introduction}

Though there are many factors which affect the long-term performance of flexible pavements but accurate evaluation of strength of subgrade soil is one of the major controlling factors, Hopper [1]. As per Indian Road Congress (IRC) [2] subgrade soil should be non-expensive in nature having more than $8 \%$. In most of the districts of Punjab, the soil conforms to the above criteria. Surprisingly the laboratory soaked CBR at 97\% of MDD (modified Proctor) were found to be $9.5 \%$. In- spite of such a higher CBR, the premature failure of roads is often reported in the electronic and print media which is a serious cause of concern for the designers, executers and quality control agencies involved the road construction sector. In this study an effort has been made to strengthen the design verification and quality control part by introducing in-situ evaluation techniques by portable devices such as Dynamic Cone Penetrometer and Light Weight Deflectometer in combination with other properties of soil that are most likely to affect the in-situ bearing capacity of soil such as grain size, liquid limit, plastic limit, maximum dry density and moisture content.

\section{Review of Previous Work}

Several researchers have attempted to correlate DCPI, modulus of elasticity and other index properties of soil with CBR. The following is a brief overview of research work available in literature. The scope of this review is limited to investigations related to CBR using DCPI, and elastic modulus (LWD), Grain size and Atterberg limits only.

\section{Correlations with Modulus of Elasticity and CBR of Soil}

Powell et al. [3] proposed the most widely accepted relationship between the CBR and the modulus of elasticity of subgrade Es measured in MPa as given in (1),

$$
\text { Es }=17.58 \times \mathrm{CBR}^{0.64}
$$

Nazzal [4] reported details of studies correlating the CBR to the elastic modulus measured using the Prima 100 LFWD $\left(\mathrm{E}_{\mathrm{fwd}}\right)$, and developed an expression as given in (2). This relationship was developed for $\mathrm{E}_{\text {fwd }}$ values ranging between 2.5 and 174.5 MPa, having $\mathrm{R}^{2}=0.83$.

$$
\mathrm{CBR}=-14.0+0.66\left(\mathrm{E}_{\mathrm{fwd}}\right)
$$

The AASHTO design guide suggests that the resilient modulus of fined grained soil can be estimated from (3) given by Heuklelom and Klomp [5]

$$
\operatorname{MR}(p s i)=1500 * \mathrm{CBR}
$$

South African Council on Scientific and Industrial 
Research (CSIR) suggests (4),

$$
\operatorname{MR}(\mathrm{psi})=3000 * \mathrm{CBR}^{0.65}
$$

And Transportation and Road Research Laboratory (TRRL) recommends (5)

$$
\operatorname{MR}(\mathrm{psi})=2555^{*} \mathrm{CBR}{ }^{0.64}
$$

Chen et al. [6] based on studies conducted by AASHTO for the design of pavements developed a correlation model (6) for the determination of the modulus of elasticity Es based on CBR. Experiments were conducted on fine-grained soils with a soaked CBR of 10 or less.

$$
\mathrm{Es}=10.34 \times \mathrm{CBR}
$$

\section{Correlations with DCPI and CBR}

Webster et al. [7] have reported the development of a relationship between the $\mathrm{CBR}$ and the penetration rate (DCPI) expressed in mm per blow (7) by the U.S. Army Corps of Engineers for a wide range of granular and cohesive materials.

$$
\log \mathrm{CBR}=2.465-1.12 \log (\mathrm{DCPI})
$$

This correlation was adopted by many researchers for their work with different soils and reported similar results, prominent and relevant to the present problem is (8) given by Livneh et al. [8] with granular and cohesive soil.

$$
\log (\mathrm{CBR})=2.45-1.12 \log (\mathrm{DCPI})
$$

Webster et al. [9] developed a much similar correlation relation (9) after conducting tests on various soils.

$$
\log (\mathrm{CBR})=2.46-1.12 \log (\mathrm{DCPI})
$$

Ese, et al. [10] carried out a detailed field and laboratory testing with DCPT, for evaluating low volume roads having gravel base course and established (10).

$$
\log \mathrm{CBR}_{(\mathrm{lab})}=2.438-1.065 * \log (\mathrm{DCPI})_{\text {field }}
$$

\section{Some Relevant Correlations with Index Properties and CBR}

NCHRP [11] guide for mechanistic-empirical design of new and rehabilitated pavement structures, developed prominent correlations of CBR with index properties of soil for non-plastic (11) and for plastic soils (12).

For non-plastic soils

$$
\text { CBR }=28.09\left(\mathrm{D}_{60}\right)^{0.358}
$$

Where $\mathrm{D}_{60}=$ the diameter corresponding to $60 \%$ finer in the particle-size distribution in $\mathrm{mm}$

And for plastic soil

$$
\mathrm{CBR}=\frac{75}{1+0.728(\mathrm{wPI})}
$$

Where $w P I=$ weighted plasticity index $=\mathrm{P}_{075} \times \mathrm{PI}$

$\mathrm{PI}=$ plasticity index of the soil in $\%$

$\mathrm{P}_{075}=\%$ passing $0.075 \mathrm{~mm}$ sieve in decimal.

Afeez Adefemi BELLO, [12] using Regression analysis on index properties of lateritic subgrade soil gave (13-16) for preliminary acceptance of soil.

$$
\begin{gathered}
\text { CBR un-soaked }=0.031(\mathrm{LL})+83.19 \\
\text { CBR un-soaked }=0.8(\mathrm{PL})+65.31 \\
\mathrm{CBR}=0.22(\mathrm{LL})+28.87 \\
\mathrm{CBR}=1.04(\mathrm{PL})+13.56
\end{gathered}
$$

As the review of previous works indicates

i). That E modulus (LWD), DCPI and Index Properties Grain Size and Plasticity Index have definite correlation with CBR of soil.

ii). The previous researchers have investigated relation of a particular parameter with CBR, the effect of other parameters is not studied. The combined effect of various parameters is essential for any correlation model to be useful in field applications.

hence, it is felt necessary to conducted a study on portable equipment with other index properties that effect the in-situ strength of soil and explore the possibility of development of some regression models, that could be helpful for field engineers of developing or under developed countries where they deal with all type of strata in one project with very limited resources.

\section{Current Practice and Its Complications}

\section{Current Design Practice}

Design of roads in most of the states in India including Punjab is carried out as per the specifications of Ministry of Road Transport and Highways and code of practice published by Indian Road Congress. Current code of practice applicable IRC-37 [2] for all important roads except village roads, for that IRC SP 72 [13] is more appropriate. The measure of subgrade strength evaluation for pavement crust design is CBR. The CBR of subgrade material is tested in laboratory at minimum assured dry density that is $97 \%$ of MDD and worst moisture conditions anticipated during the design life of road, normally soaked condition is considered for major roads. In case there is considerable difference between CBR of the Subgrade and underlying embankment layer the effective CBR is considered for design [14]. The minimum recommended CBR for subgrade is $8 \%$ [2].

\section{Current Quality Control Practice}

For quality assurance, soil samples are tested for CBR at $97 \%$ of MDD and moisture content considered for design (soaked/un-soaked etc.) [15]. The approved borrow pit soil report has $\mathrm{MDD}, \mathrm{OMC}$ and $\mathrm{CBR}$ at $97 \%$ dry density that is the minimum compaction limit as MORT\&H [16]. During construction, the control is only on OMC and Dry Density that is to be checked through one set of ten test samples per 3000 sqm of compacted layer of $200 \mathrm{~mm}$ thickness [15], the determination of density shall be as per IS:2720 Part-28 [17]. 
To meet with the density criteria is considered as synonymous to meeting strength/CBR.

\section{Complications in Quality Assurance}

Soil in major part of the Punjab consists of alluvium of varying thickness. While borrowing soil from such an area chances of blending of different alluvium layers is very high and can lead to altogether different properties [18]. Testing the subgrade for density only can lead to misrepresentation of subgrade strength, thus requiring intensive testing. In engineered fill or prepared subgrades, verification of relative density is carried out using sand cones or nuclear densometers which relate soil properties to the measured or inferred soil density. The field density by sand replacement is simple but time consuming; the nuclear density gauge has its own environmental and health issues. Presence of large size particles gives erroneous results, to increase the level of confidence number of tests can be increased but it is impracticable. Mixing of different soils during construction can change the maximum density thus causing problems in correlating the density. Compaction more than $100 \%$ of maximum dry density is very common in field testing that is due to mixing or change in soil in borrow area. The other in-situ method of testing the subgrade strength is field CBR method, since the subgrades are essentially non-plastic in nature it is not recommended to conduct field CBR test [2].

\section{Materials and Methods}

Alternatively, the soil properties can be measured or calculated by direct measurement of the response of the soil to applied loads or correlated to penetration resistance of various probes. The various techniques which can be used to measure the direct response of the soil when subjected to loads are static plate test, LWD, Clegg Hammer, Geo Gauge, time domain reflectometry and other means. Penetration resistance can be conducted with portable penetrometers by measuring the number of blows for a given penetration or the penetration per blow. All these methods have their pros and cons, and lack of general acceptability. In this study DCP and LWD along with other engineering properties such as dry density, grain size, liquid limit and plastic limit are used. The LWD is a quick and repeatable test that is not influenced by large aggregate, proximity to metal reinforcement and fill end effects. However, the soil modulus determined by the LWD is moisture sensitive for low permeability soils or for saturated high permeability soils [19]. The portable Standard Dynamic Cone Penetrometer (DCP) comprises a drive rod fitted with a cone at the tip and is operated by dropping an 8 $\mathrm{kg}$ mass from a specified height. LWD and DCP produce results that can be correlated well to the California Bearing Ratio (CBR) and density of a particular soil. The other soil parameters and can also be used to fine tune the results and little wider type of soils up to the significant depth of influence of traffic load. Both these tests can be conducted very quickly only two persons are required to operate and to shift from one location to another. The above stated benefits of these two equipment help in controlling the quality in a better way because large number of in-situ tests can be conducted at smaller intervals. Moreover, in-situ tests are preferred over laboratory tests as it is very difficult to reproduce the field conditions in laboratory samples.

To meet out such challenges researchers are constantly trying to explore the possible use of portable instruments for in-situ testing and establishing the correlations with other test results of soil and aggregate through laboratory and field testing. However, large scale testing with variety of instruments needs to be carried out, specifically if it is to be used as part of construction and quality assurance contract.

Various researchers and government agencies have developed the relationships between in-situ tests such as Dynamic Cone Penetration Index (DCPI) versus CBR, and dynamic modulus of elasticity $\left(\mathrm{E}_{\text {mod }}\right.$ ) versus $\mathrm{CBR}$. Equation (3) developed by American Association of State Highway and Transportation Officials (AASHTO) [20], and similar other equations detailed in review of previous works are over simplified to be used in actual construction projects having financial obligations. To overcome the shortcomings an effort has been made to find the effect of some of other soil parameters that directly affect the results obtained from relations described in [2].

To study the possibilities of using DCP and LWD in road construction to measure the in-situ strength by penetration rate and deflection of compacted subgrade respectively that are comparable with CBR. The DCP test is conducted by driving a cone into the soil with a standard weight of $8 \mathrm{~kg}$, to measure shear strength. LWD measures the deflections by dropping a weight of 8-20 kg.

Whether measuring density, modulus, or shear strength, the moisture content remains a critical quality control parameter. Therefore, the moisture content needs to be measured, or estimated with a high degree of accuracy, at each location. In this study LWD and DCP is used and the moisture is kept at $\mathrm{OMC}+/-2 \%$ at which soil is placed in subgrade and unsaturated CBR tests are performed. Study is carried out at fifteen different test strips of $300 \mathrm{~m} \times 10 \mathrm{~m}$ which are part of a $45 \mathrm{~km}$ long under construction road along the Sirhind Canal in Punjab State. The subgrade is tested immediate after lying to keep the moisture content near to OMC. Various in-situ properties such as field density, field moisture content, in-situ dynamic cone penetration index (DCPI) and surface modulus $\left(\mathrm{E}_{\mathrm{mod}}\right)$ are determined at all fifteen locations shown in (Figure 1).

\section{Light Weight Deflectometer Apparatus and Test Procedure}

The Light Weight Deflectometer (LWD) is a portable version of the FWD. The LWD uses a load cell and geophones with the same accuracy as the FWD. The LWD can be used to directly test the unbound subbase and subgrade. The output from the LWD can also be used to calculate the strength of multiple pavement layers. LWD used in this study is Dynatest 3031 (Figure 2), it meets the 
requirements for determining the modulus of a material approved by American Society for Testing and Materials (ASTM) [21].

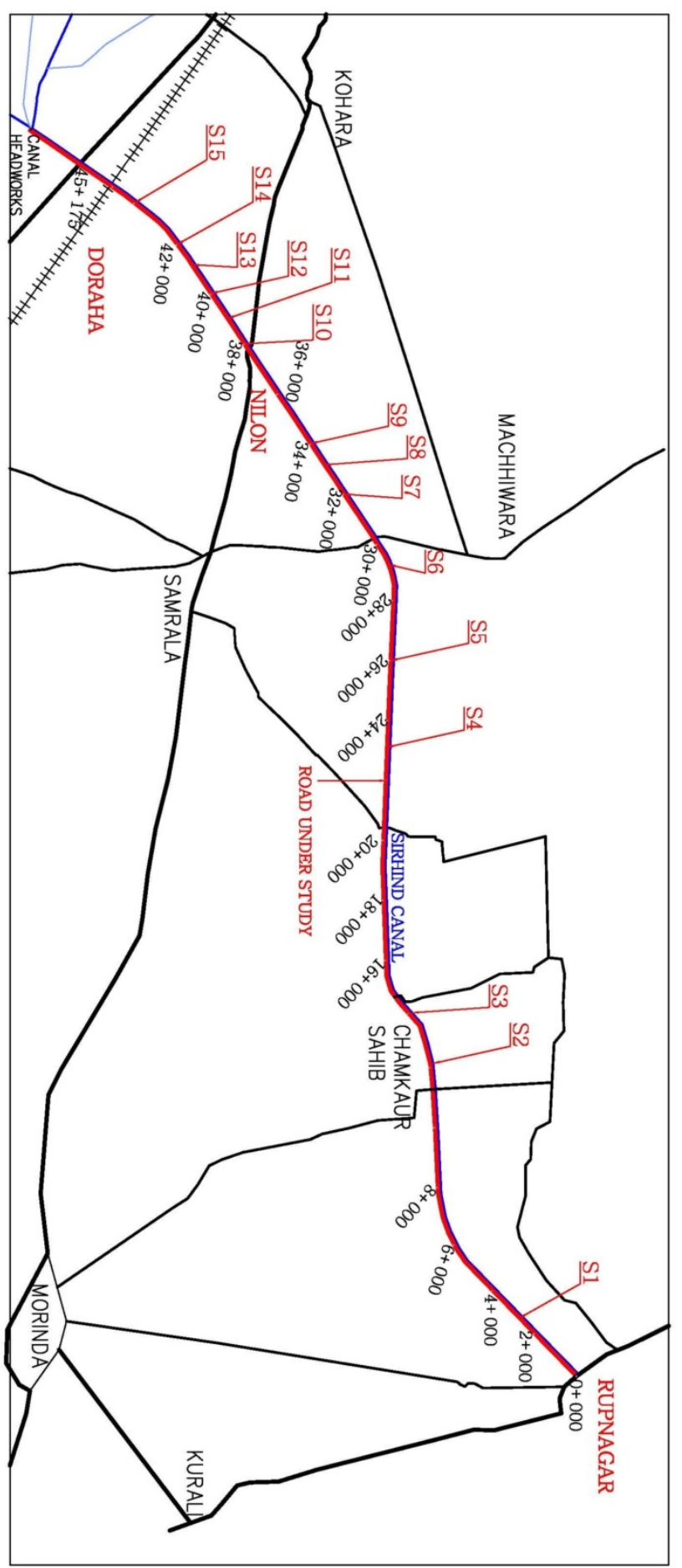

Figure 1. Sample Locations shown on key plan of Road along Sirhind Canal from Rupnagar to Doraha $(45+175 \mathrm{KM})$

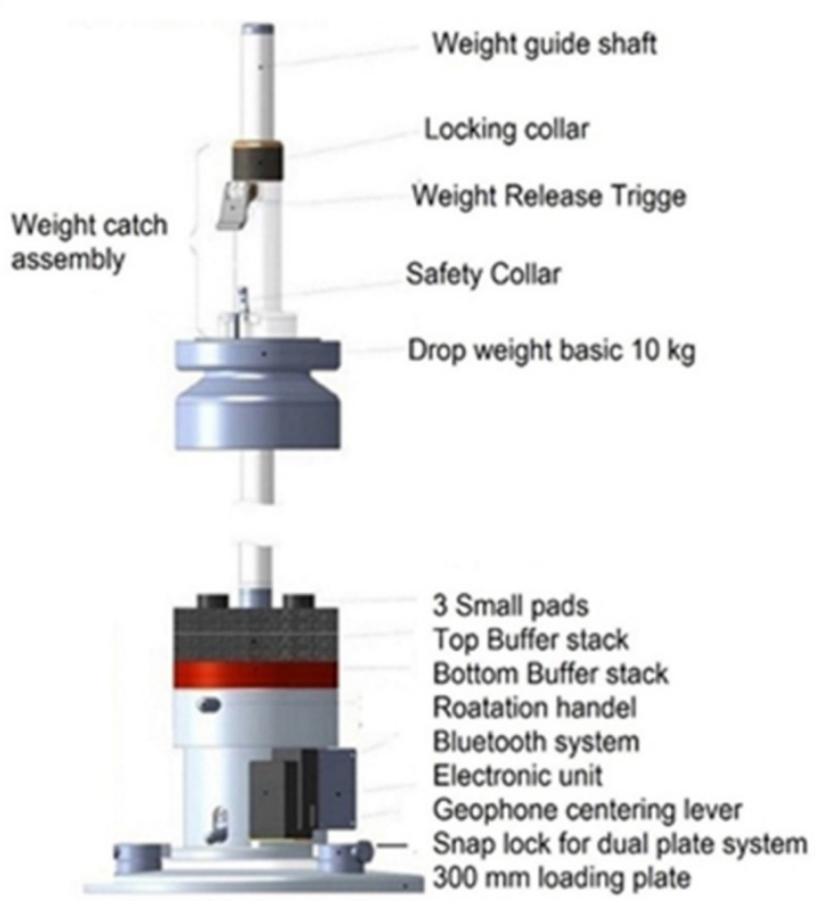

Figure 2. Light Weight Deflectometer

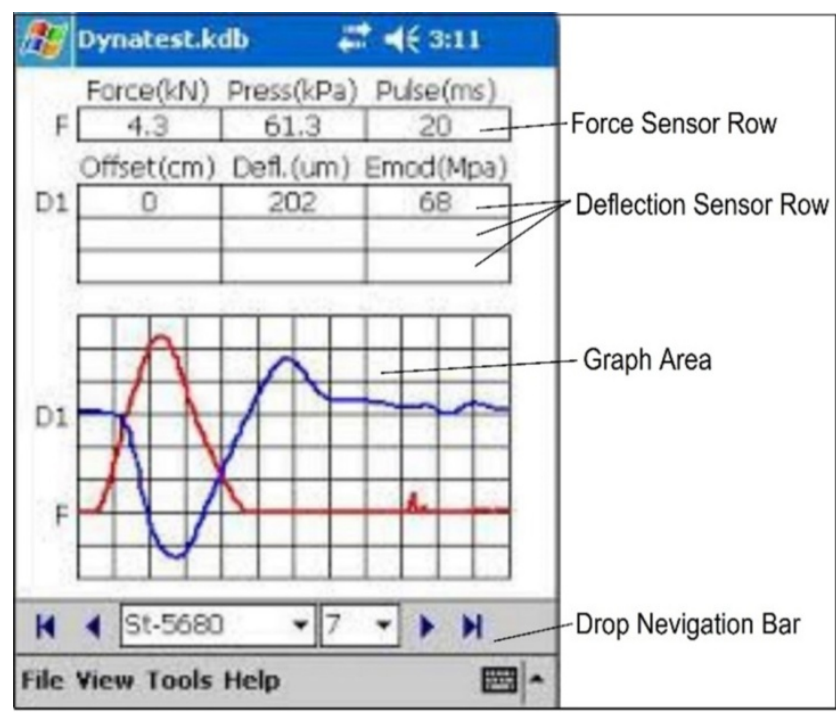

Figure 3. Light Weight Deflectometer output screen

LWD devices are configured and used differently as per the manufacturer's instructions depending on the model and working conditions. The results of LWD vary with applied force, type and location of deflection sensor, plate diameter and rigidity, and buffer stiffness (Vennapusa and White [22]. During operation, the plate is first placed directly over level ground and 3 initial blows of the drop weight are given to ensure a close contact Frost et al. [23]. A subsequent 3 drops of the weight are performed and the data acquisition system calculates the deformation (deflection) for each blow and display subgrade surface modulus $\mathrm{E}_{\bmod }$ and deflection on the output screen (Figure 3) that is downloadable for further analysis using software. The 
surface modulus $\mathrm{E}_{\mathrm{mod}}$ is calculated by (17).

$$
\text { Emod }=\frac{1.5 r \sigma}{s}
$$

where:

$\mathrm{r}$ is the radius of the load plate,

$\sigma$ is the stress below the plate and

$\mathrm{s}$ is the measured deflection or settlement.

LWDs are being used to spot check unbound material compaction in parts of Europe, Fleming et al. [24], and are beginning to be used in the United States, Mooney et al. [19]; Vemmapusa and White [22]; White et al. [25]. LWD offer several advantages over the specified density method. On a practical level, LWD tests take less time, have greater precision, and are able to accurately test more material types. For example, large aggregate creates problems for other tests. In addition, LWD testing is reliable as field supervisor is able to witness the whole test process at site as it is fully visible during testing.

\section{Dynamic Cone Penetrometer Apparatus and Test Procedure}

The DCP consists of an upper fixed $575 \mathrm{~mm}$ travel rod with $8 \mathrm{~kg}$ falling weight, a lower rod containing an anvil, and a replaceable cone with apex angle of $60^{\circ}$ or $30^{\circ}$ and having diameter of $20 \mathrm{~mm}$ (Figure 4). in this study $60^{\circ}$ cone is used The test is conducted by dropping the weight from $575 \mathrm{~mm}$ height and recording the number of blows versus depth. Then the penetration rate, PR (sometimes referred as DCP ratio, or penetration index PI) is calculated. DCP tests are designed to estimate the structural capacity of pavement layers and embankments. The DCP has the ability to verify both the level and uniformity of compaction, which makes it an excellent tool for quality control of pavement construction. The DCP test is conducted as per standard procedure IRC-Special Publication [26] and ASTM [27].

$$
\begin{gathered}
D P I(\text { Seating })=\frac{D-D(\text { Initial reading })}{2(\text { drops })} \\
D P I(1)=\frac{D 7-D 3}{5(\text { drops })} \\
D P I(2)=\frac{D 8-D 12}{5(\text { drops })}
\end{gathered}
$$

Where DPI=DCP penetration index $(\mathrm{mm} / \mathrm{drop})$ and $\mathrm{DN}=$ Depth of penetration after Nth drop in $(\mathrm{mm})$

\section{Results and Discussion}

All the soil samples were tested for laboratory compaction characteristics MDD \& OMC, Strength characteristics (laboratory CBR at OMC and 97\% density of MDD), particle size analysis $\left(\mathrm{D}_{10}, \mathrm{D}_{30}\right.$ and $\left.\mathrm{D}_{60}\right)$, Atterberg limits (LL and PL), field compaction and field moisture to ensure that the field conditions of compaction and moisture are in accordance to laboratory conditions, field measurement of strength in terms of DCPI ( $\mathrm{N} \mathrm{mm} / \mathrm{blow})$ with the help of standard DCPT apparatus and surface modulus $\mathrm{E}_{\text {mod }}$ with the help of Dynatest 3031 LWD.

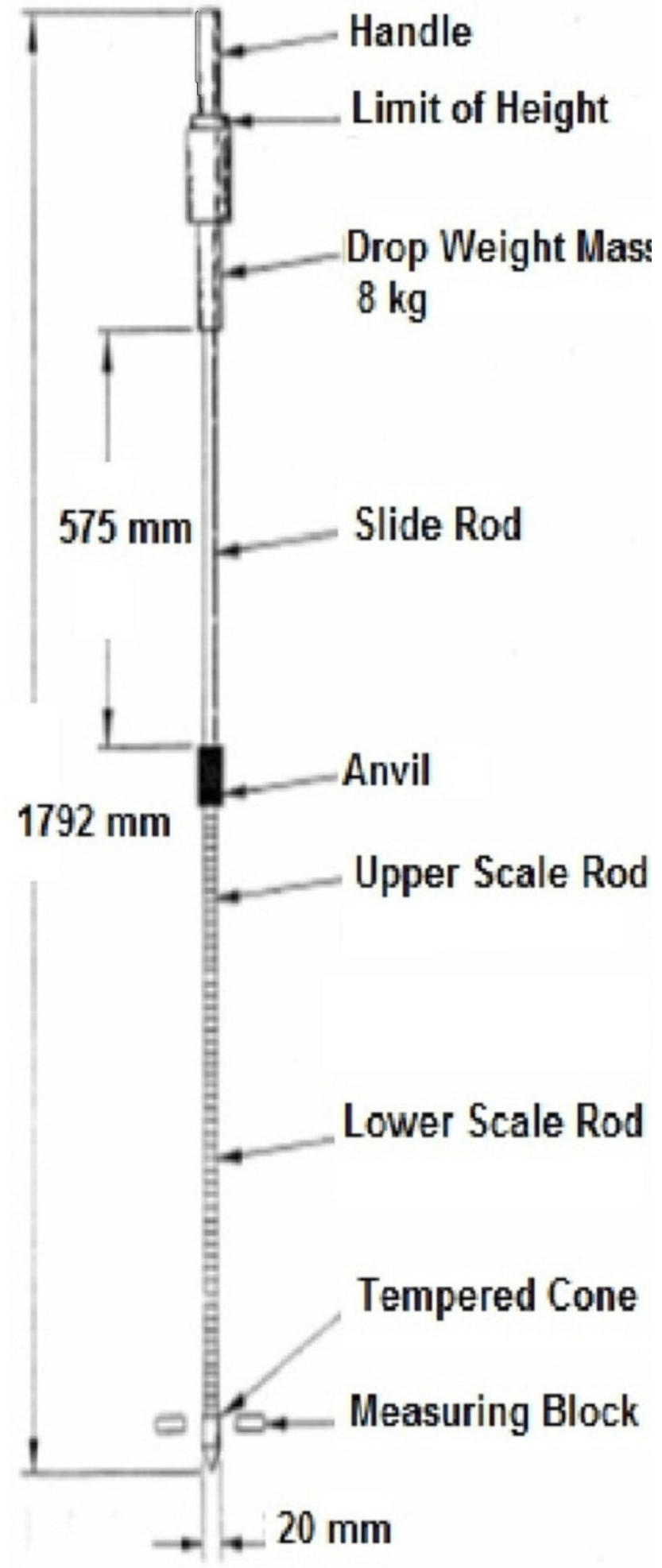

Figure 4. Dynamic Cone Penetrometer

(Figure 5) gives an overview of grain sizes of soils tested during investigation. From the graph, it can be read that the soil tested have $\mathrm{D}_{60}$ grain size from $0.925 \mathrm{~mm}$ to $0.045 \mathrm{~mm}$ and $\mathrm{D}_{30}$ from $0.374 \mathrm{~mm}$ to $0.021 \mathrm{~mm}$ and most of them are well graded. 


\section{Correlation between Dry Density and CBR}

The CBR of all the 15 samples was determined at $97 \%$ of MDD at OMC. From the analysis of results and (21) having $\mathrm{R}^{2}$ 0.1087, it is observed that there is no significant relationship between dry density and CBR of different soils as shown in (Figure 6).

$$
\mathrm{CBR}=-0.2314 \gamma_{\mathrm{d}}{ }^{2}+10.283 \gamma_{\mathrm{d}}-96.738
$$

$\mathrm{R}^{2}=0.1087$.

The reason may be fine grained soils having less voids and better compactability due to low interparticles friction at OMC, thus have low CBR. Thus density versis CBR relationship for variety of soils is not feasible, thus results are as expected.

\section{Correlation between Grain Size $\mathrm{D}_{\mathbf{6 0}}$ and $\mathrm{CBR}$}

To study the effect of grain size on CBR, grain size vs. CBR plot for $\mathrm{D}_{10}, \mathrm{D}_{30}$ and $\mathrm{D}_{60}$ were drawn and found that $\mathrm{D}_{60}$ vs CBR has most significant correlation (22) as shown in (Figure 7).

$$
\mathrm{CBR}=1.1323\left(\mathrm{D}_{60}\right)^{2}+19.576\left(\mathrm{D}_{60}\right)+9.214
$$

Having $\mathrm{R}^{2}=0.9086$.

The results are very near to the results obtained from (11) of NCHRP [11] for non-plastic soils. The results for plastic soils having plasticity more than 6 are somewhat near to the (12) of NCHRP [11]. That strengthens the research problem that for in-situ subgrade soil having mixed soils, applicability of available equations is doubtful.

\section{Correlation between DCPI and CBR}

Similarly, significant relationship (23) between DCPI (N $\mathrm{mm} /$ blow) and CBR of soil exists as shown in (Figure 7).

$$
\mathrm{CBR}=0.2481 \mathrm{~N}^{2}-7.7369 \mathrm{~N}+71.197
$$

Having $\mathrm{R}^{2}=0.7431$

The results for non-cohesive soils are very near to $(7,8,9)$ whereas the results given by (10) are on higher side, it is due to the reason that (10) is specifically for granular material.

\section{Correlation between $\mathbf{E}_{\text {mod }}$ and CBR}

The modulus of elasticity of in-situ soil subgrade measured and a plot shown in (Figure 9) is drawn to find the correlation (24) and R-square value.

$$
\mathrm{CBR}=0.0091\left(\mathrm{E}_{\mathrm{mod}}\right)^{2}-0.5191\left(\mathrm{E}_{\mathrm{mod}}\right)+15.982
$$

With $\mathrm{R}^{2}=0.8408$, holds a significant relationship with tested soils.

The results obtained are comparable with results given in $(1,2)$ up to an extent of trend only. The numerical values vary considerably, it is due the fact that each instrument has its own calibration and stiffness of the soil immediately below the layer under testing also affects the results considerably.

\section{Correlation between LL, PL and CBR}

The effect of liquid limit and plastic limit on CBR of soils is also studied, the results are plotted in (Figure 10) and (Figure 11), the correlations found are

$$
\mathrm{CBR}=0.3171(\mathrm{LL})^{2}-13.934(\mathrm{LL})+163.52
$$

And

$$
\mathrm{CBR}=1.1641(\mathrm{PL})^{2}-43.869(\mathrm{PL})+424.7
$$

Having a $\mathrm{R}^{2}=0.805$ and $\mathrm{R}^{2}=0.8458$ respectively indicates that LL and PL have significant impact on CBR of soils.

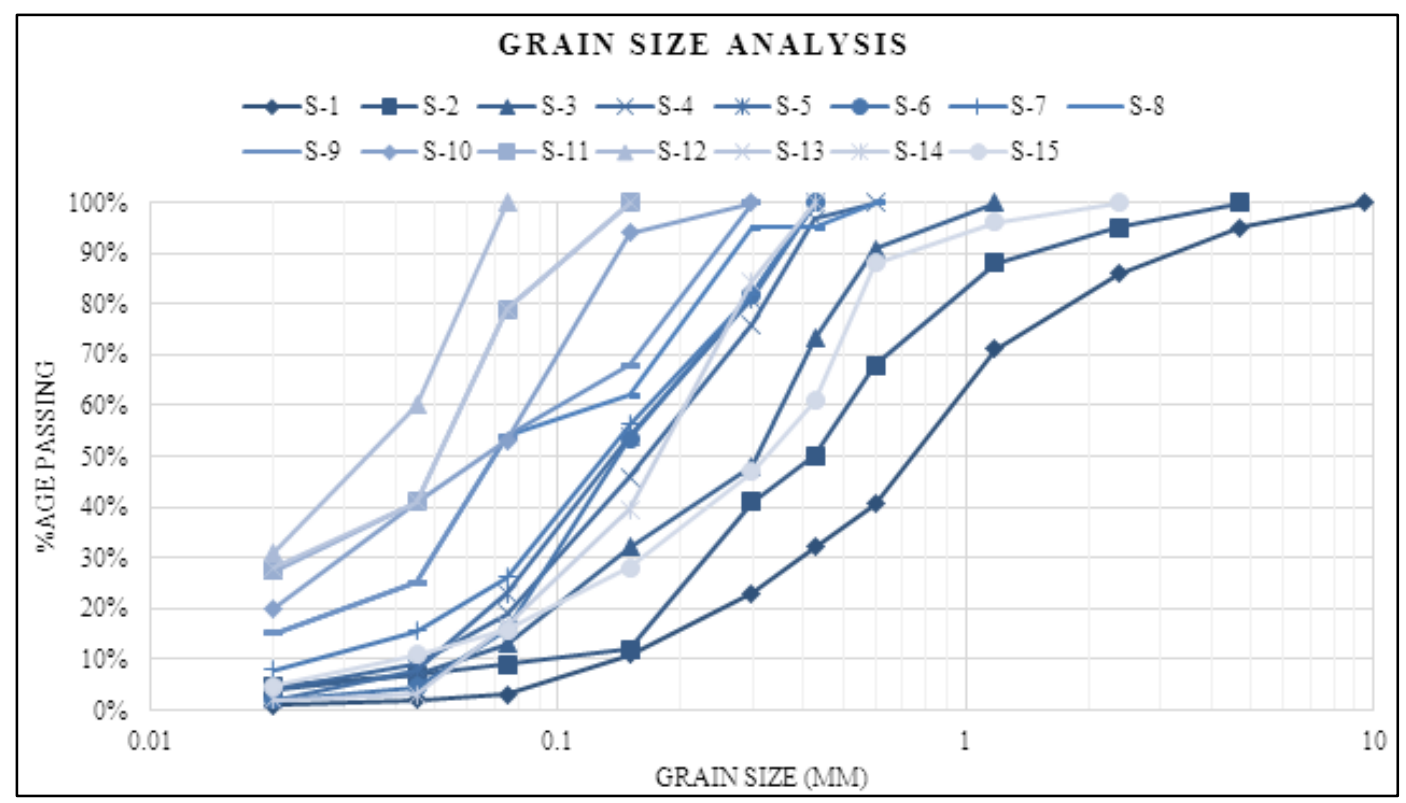

Figure 5. Grain Size Analysis for $D_{10}, D_{30}$ and $D_{60}$ 


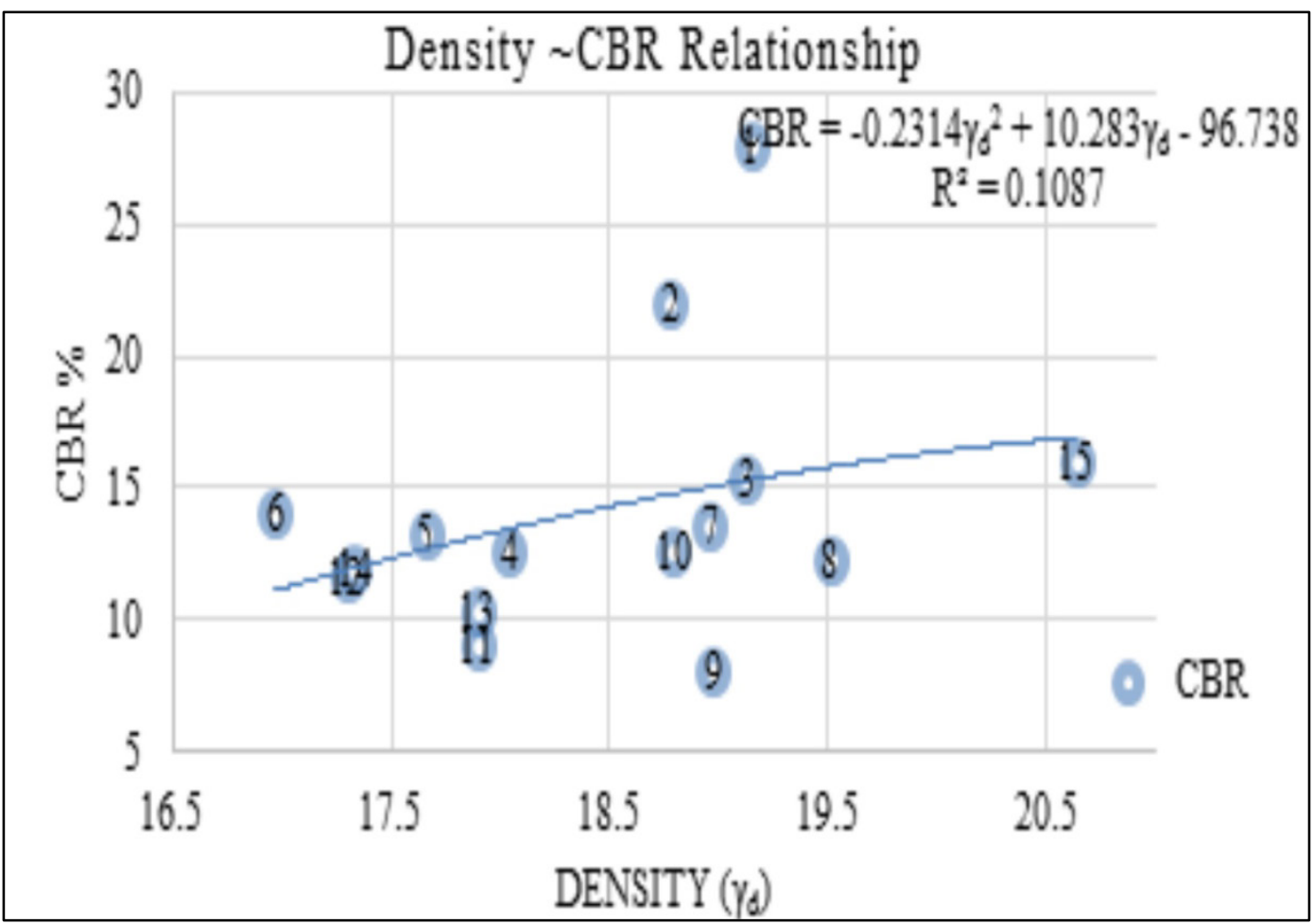

Figure 6. Density $\sim$ CBR Relationship

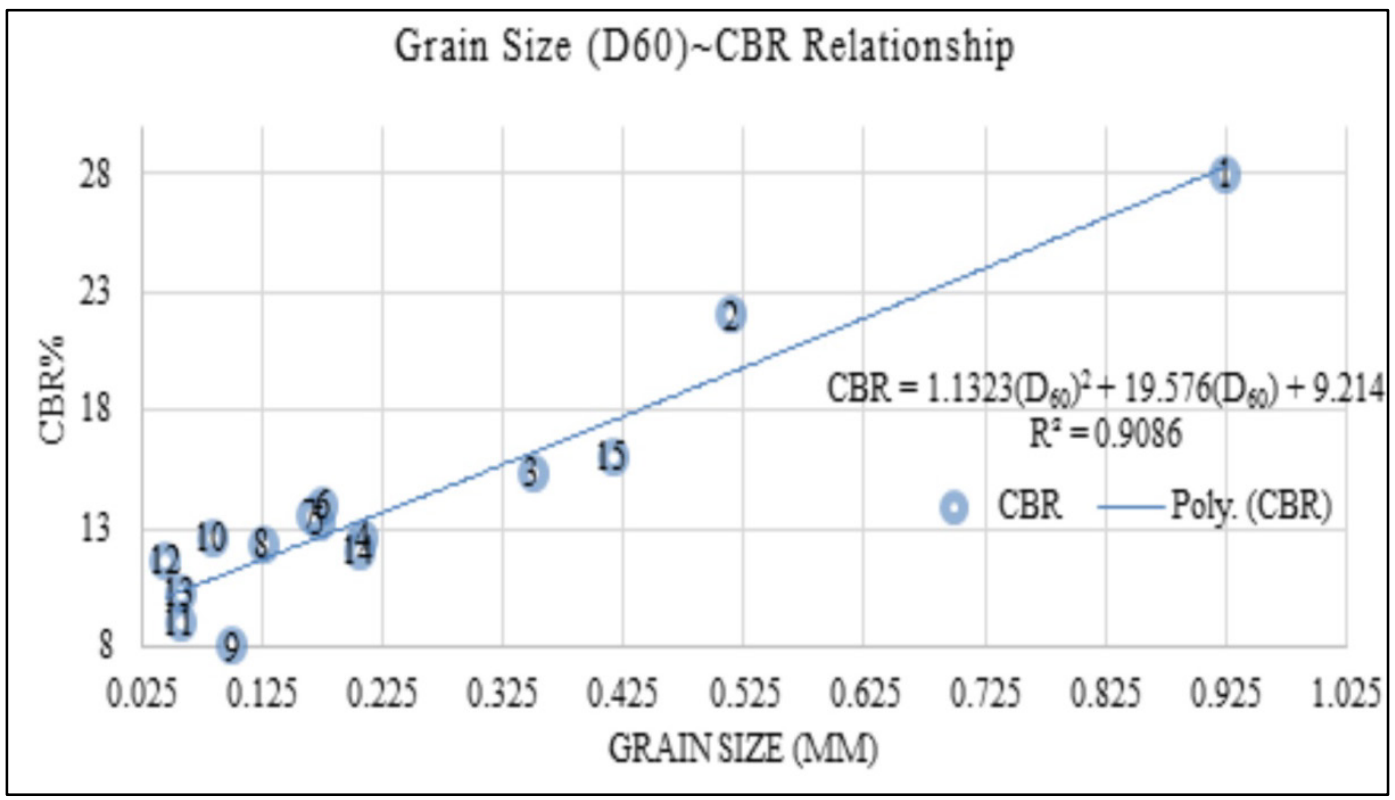

Figure 7. Grain Size $\left(D_{60}\right) \sim$ CBR Relationship 


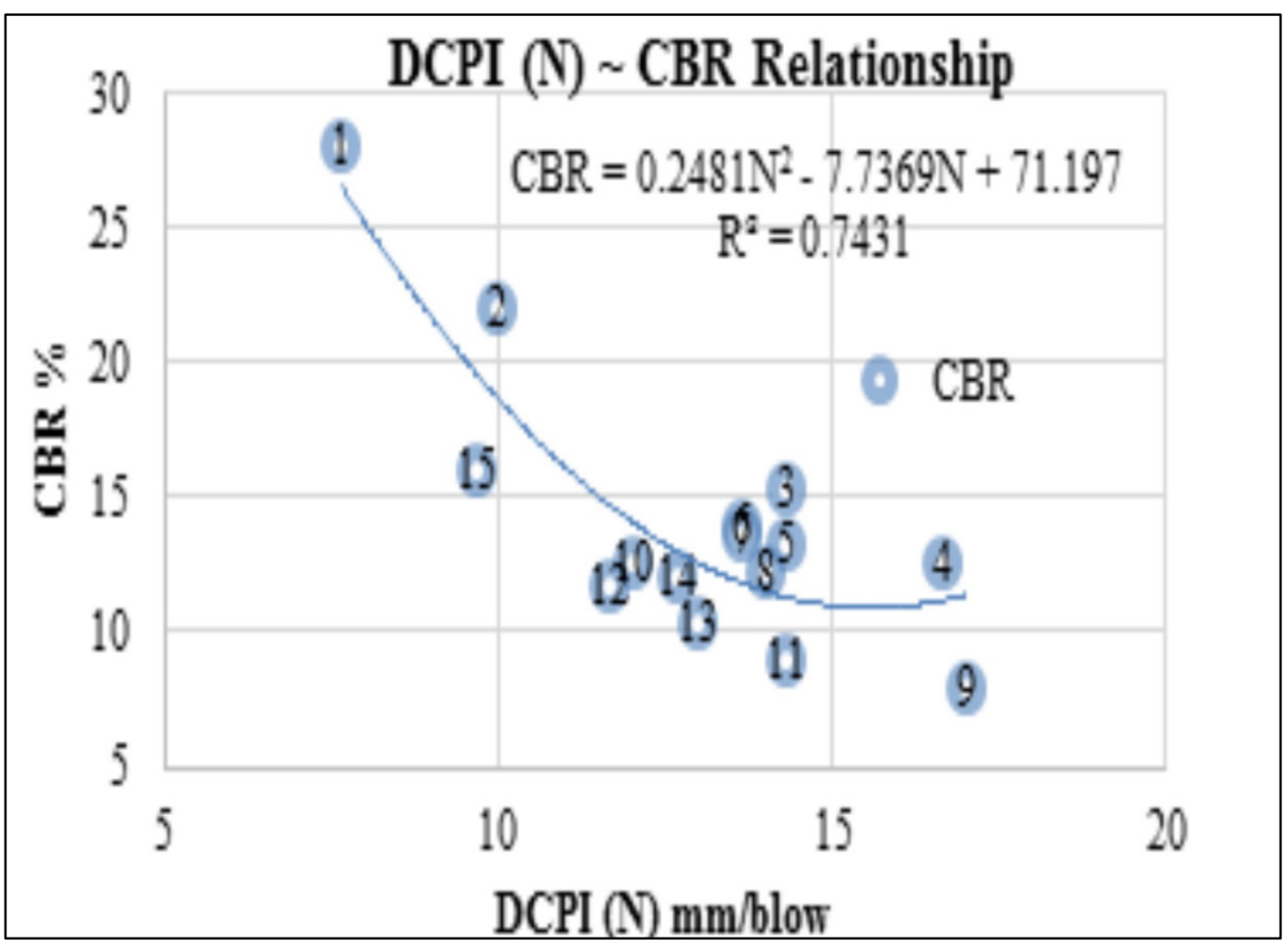

Figure 8. DCPI $(\mathrm{N}) \sim$ CBR Relationship

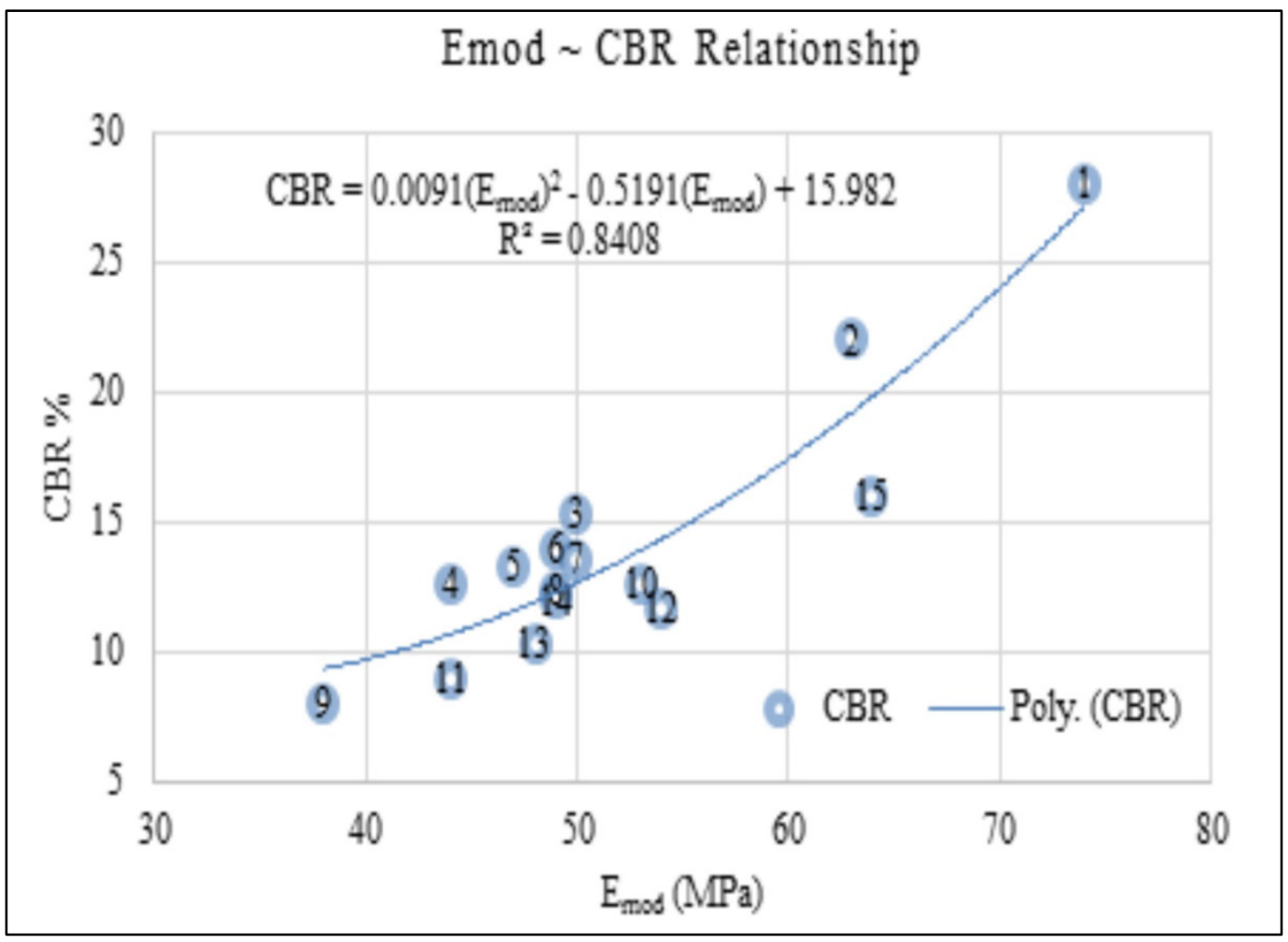

Figure 9. $\mathrm{E}_{\bmod } \sim \mathrm{CBR}$ Relationship 


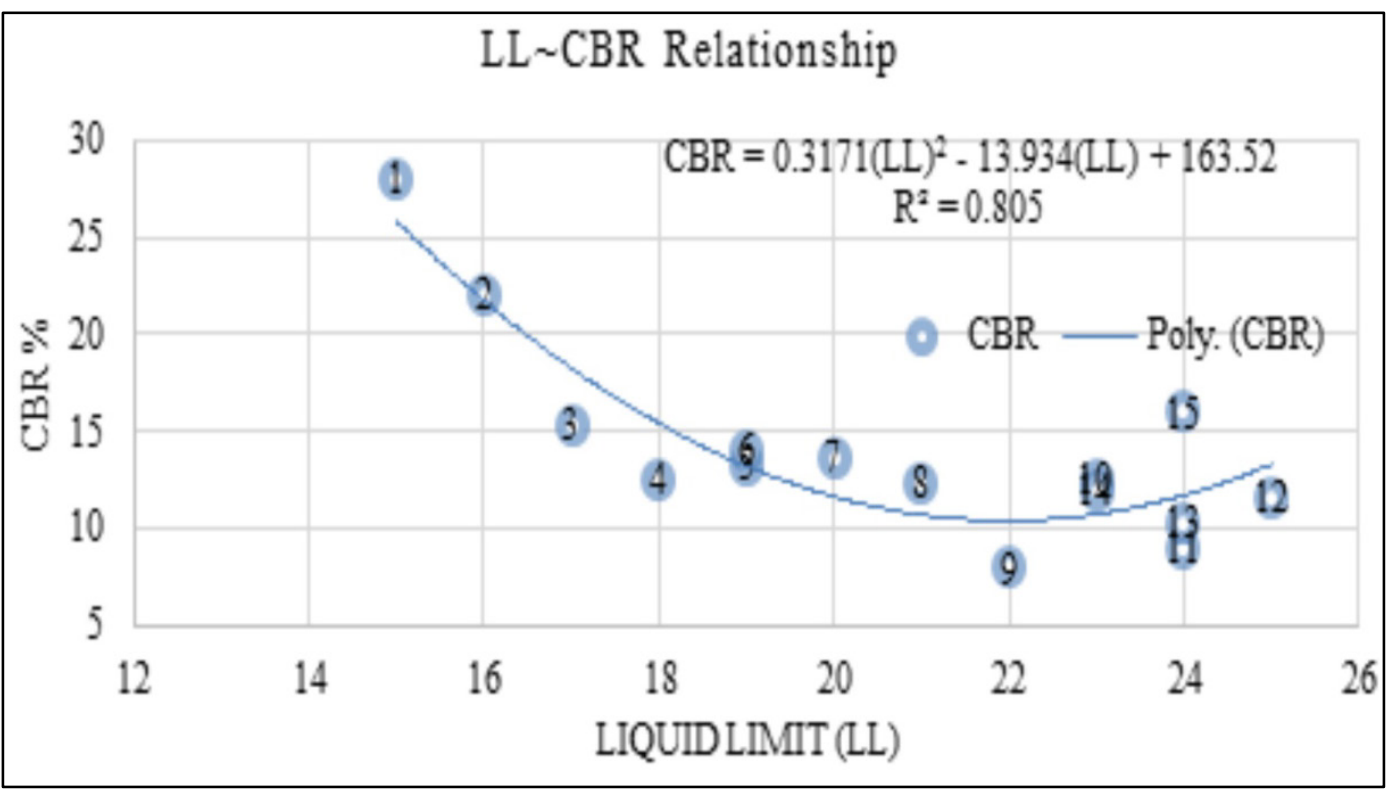

Figure 10. LL $\sim$ CBR Relationship

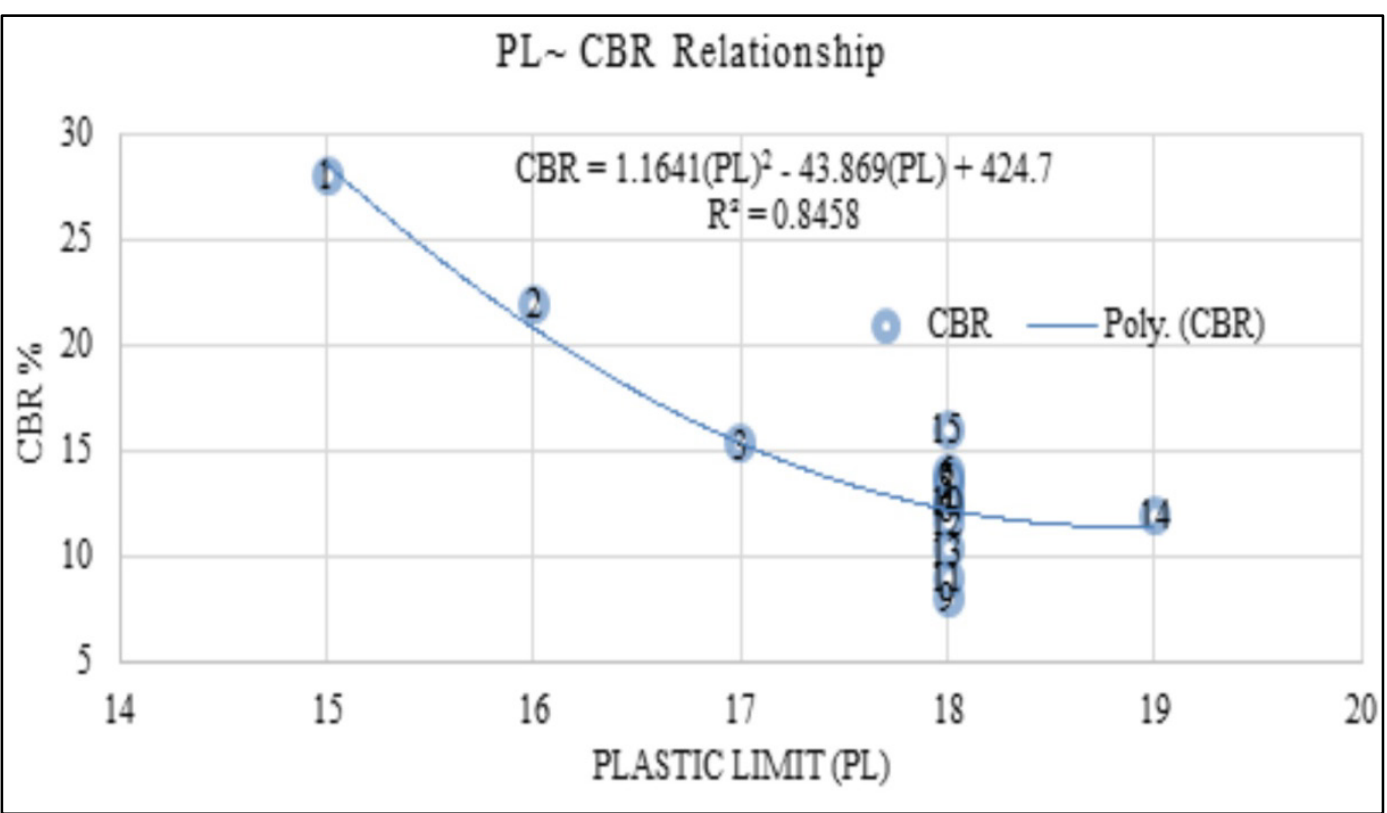

Figure 11. PL $\sim \mathrm{CBR}$ Relationship

Table 1. ANOVA results DCPI based in-situ CBR prediction model

\begin{tabular}{|c|c|c|c|c|c|}
\hline & df & SS & MS & F & Significance F \\
\hline Regression & 4 & 355.578188 & 88.894547 & 535.256075 & $1.2979 \mathrm{E}-11$ \\
\hline Residual & 10 & 1.66078539 & 0.16607854 & & \\
\hline Total & 14 & 357.238973 & & & \\
\hline
\end{tabular}

Table 2. ANOVA results LWD $\left(\mathrm{E}_{\mathrm{mod}}\right)$ based in-situ CBR prediction model

\begin{tabular}{|c|c|c|c|c|c|}
\hline & df & SS & MS & F & Significance F \\
\hline Regression & 4 & 355.2935449 & 88.82338623 & 456.5749426 & $2.86061 \mathrm{E}-11$ \\
\hline Residual & 10 & 1.945428405 & 0.194542841 & & \\
\hline Total & 14 & 357.2389733 & & & \\
\hline
\end{tabular}


The above results are as expected since higher Liquid Limit indicates of presence of clay particle thus increase in clay contents decreases the CBR of soil. An increase in CBR with increase in LL in some samples may be due the better compaction of coarser particles due to presence of more fine particles. The result is similar for Plastic Limit, CBR relationship. For lateritic soils [12] gave correlations (13-16) in which increase in LL and PL shows an increase in CBR, this is possible up to a limited extent, till the presence of clay particles help in compaction.

Taking all the parameters having significant relationship with CBR, standard linear regression analysis is carried out to develop prediction models one from DCPI $(\mathrm{N})$ grain size $\mathrm{D}_{60}$ and Atterberg's limits LL and PL of soil.

In-situ CBR of subgrade at OMC and 97\%MDD

$$
=43.73-1.043 \mathrm{~N}-0.717 \mathrm{LL}-0.149 \mathrm{PL}+5.39 \mathrm{D}_{60}
$$

With $\mathrm{R}^{2}=0.995$ and a standard error of 0.407 . The results of the ANOVA test are summarized in Table 1.

Since the P-value is 1.2979E-11, which is much less than the significance value of 0.05 , the null hypothesis is rejected. So, we can say that, there is a relation between the CBR and the variables proposed in the model.
Another model based on dynamic modulus of subgrade surface $\mathrm{E}_{\text {mod, }}$ and keeping all other parameters same.

$$
=11.538+0.344 \mathrm{E}_{\mathrm{mod}}+2.95 \mathrm{D}_{60}-0.588 \mathrm{LL}-0.217 \mathrm{PL} \text { (28) }
$$

With $\mathrm{R}^{2}=0.995$ and a standard error of 0.441 , the results of the ANOVA test are summarized in Table 2.

Since the P-value is $2.86061 \mathrm{E}-11$, which is much less than the significance value of 0.05 , the null hypothesis is rejected. So, we can say that, there is a relation between the CBR and the variables proposed in the model.

\section{Validation}

To validate the research models, the results are compared with laboratory test results on another ongoing National Highway No. NH-95 project. Properties of soils along with test results and predicted CBR given by both the models is tabulated in Table 3. From the table, it can be concluded that the results predicted by both the models are well in acceptable range up to the grain size and is with in permissible limits.

\begin{tabular}{|c|c|c|c|c|c|c|c|c|c|c|c|}
\hline \multirow{2}{*}{$\begin{array}{c}\text { Sample } \\
\text { Reference }\end{array}$} & \multirow{2}{*}{$\begin{array}{c}\text { Laboratory } \\
\text { CBR } \\
\text { (\%) }\end{array}$} & \multirow{2}{*}{$\begin{array}{c}\mathrm{N} \\
(\mathrm{mm} / \\
\text { blow) }\end{array}$} & \multirow{2}{*}{$\begin{array}{l}E_{\text {mod }} \\
(\mathrm{mPa})\end{array}$} & \multirow{2}{*}{$\begin{array}{c}\mathrm{D}_{60} \\
(\mathrm{~mm})\end{array}$} & \multirow{2}{*}{$\begin{array}{l}\text { Liquid } \\
\text { Limit- } \\
(\%)\end{array}$} & \multirow{2}{*}{$\begin{array}{c}\text { Plastic } \\
\text { Limit } \\
(\%)\end{array}$} & \multicolumn{4}{|c|}{ Predicted CBR (\%) } & \multirow[b]{2}{*}{ Remarks } \\
\hline & & & & & & & $\begin{array}{l}\text { DCPT } \\
\text { Model }\end{array}$ & $\begin{array}{l}\text { \%age } \\
\text { Error }\end{array}$ & $\begin{array}{l}\text { LWD } \\
\text { Model }\end{array}$ & $\begin{array}{l}\text { \%age } \\
\text { Error }\end{array}$ & \\
\hline VS-1 & 9.3 & 13.6 & 48 & 0.09 & 25 & 19 & 9.27 & -0.32 & 9.48 & 1.94 & Valid \\
\hline VS-2 & 12.6 & 12.8 & 52 & 0.1 & 22 & 18 & 12.46 & -1.11 & 12.87 & 2.14 & Valid \\
\hline VS-3 & 8.1 & 18.2 & 35 & 0.12 & 20 & 18 & 8.37 & 3.33 & 8.26 & 1.98 & Valid \\
\hline VS-4 & 8.5 & 19.6 & 32 & 0.15 & 18 & 17 & 8.65 & 1.76 & 8.71 & 2.47 & Valid \\
\hline VS-5 & 10.1 & 19.2 & 35 & 0.16 & 17 & 17 & 9.84 & -2.57 & 10.36 & 2.57 & Valid \\
\hline VS-6 & 9.3 & 19.2 & 33 & 0.175 & 18 & 15 & 9.5 & 2.15 & 9.56 & 2.8 & Valid \\
\hline VS-7 & 24.9 & 7.33 & 73 & 0.71 & 17 & 17 & 25.19 & 1.16 & 25.05 & 0.60 & Valid \\
\hline VS-8 & 34.8 & 1.66 & 70 & 2.26 & 15 & 15 & 41.19 & 18.36 & 30.2 & -13.22 & Not valid \\
\hline VS-9 & 47.6 & 1.33 & 90 & 4.5 & 15 & 15 & 53.61 & 12.63 & 43.69 & -8.21 & Not valid \\
\hline
\end{tabular}

Table 3. Lab CBR and Predicted CBR with different models

From the above results, it can be concluded that results given by the models are valid up to the grain size tested during the study. Sample VS-1 to Vs-7 is soil having grain size within the limits of the soils used in study, whereas sample VS-8 and VS-9 soil is much coarser and less LL and PL as compared to the soils used in study. 


\section{Conclusions}

From the present study, the followings conclusions are drawn:

1. In-situ Subgrade strength can easily be ascertained using DCPT and other index properties of soil such as LL, PL, $\mathrm{D}_{60}$ grain size, as a valid relation (27) of these parameters exists with $\mathrm{CBR}$. The relation given in IRC:37[2] for determination of CBR, $\log _{10} \mathrm{CBR}=$ $2.465-1.12 \log _{10} \mathrm{~N}(7)$, cannot be used blindly for evaluation of in-situ CBR of fine grained plastic subgrade soil, as liquid limit, plastic limit and particle size of soil have significant impact on the CBR of soil.

2. The subgrades consisting of different soils can be tested in-situ condition with reasonable accuracy with the help of LWD. The valid relationship exists between laboratory $\mathrm{CBR}, \mathrm{E}_{\mathrm{mod}}, \mathrm{LL}, \mathrm{PL}$ and $\mathrm{D}_{60}$ particle size of the soils. There exists a significant relationship between $\mathrm{E}_{\text {mod }}$ and $\mathrm{CBR}$ of soil (28), but CBR determined from individual relationship between $\mathrm{E}_{\text {mod }}$ and Laboratory CBR could be misleading since other factors viz Liquid Limit, Plastic Limit and grain size also play pivotal role in assessment of CBR.

3. DCPT and LWD models with other index properties are more suitable for important road works where stacks are comparatively high. Simple determination of density is not reliable method to ascertain the in-situ strength of soil subgrade. The models proved to be efficient and valuable aid in in-situ testing of compacted soil layers with proven repeatability.

4. In-situ CBR prediction models prepared are valid only for the type of soil having parameters within the range of parameters investigated during study, in case of soil having parameters that falls away from the data analysed separate prediction model would be required.

5. This study is conducted at OMC, change in moisture content other than OMC can severely affect the results.

6. Further studies can be carried out tacking additional effect of relative density, moisture content and temperature on CBR.

\section{Acknowledgements}

Authors are very thankful for the cooperation of staff and faculty of Guru Nanak Dev Engineering College Ludhiana, Punjab, Engineers of Public Works department Punjab, Field Engineers of Execution Agencies for their cooperation and sharing valuable information without which this work wasn't possible.

\section{REFERENCES}

[1] Hopper, W.D. 1988. The World Bank. Road Deterioration in
Developing Countries, Washington, D.C.: A World Bank Policy Study.

[2] Indian Road Congress, Code of practice, Guidelines for the design of flexible pavements IRC 37: 2012. The Indian Road Congress New Delhi, India.

[3] Powell, W. D., Potter, J. F., Mayhew, H. C., and Nunn, M. E. 1984. The structural design of bituminous roads, TRRL report LR 113, 62, (TRRL: London)

[4] Nazzal, M. 2003. Field evaluation of in-situ test technology for QC/QA procedures during construction of pavement layers and embankments, MS thesis, Baton Rouge: Louisiana State University.

[5] Heuklelom, W., and Klomp, A. J. G., (1962), "Dynamic Testing as a Means of Controlling Pavements During and After Construction." Proceedings, 1st Int. Conf. on Struct. Des. Of Asphalt Pavement, University of Michigan, Ann Arbor, Mich., 667-679

[6] Chen, D. H., Lin, D. F., Pen-Hwang Liau, P. H., and Bilyeu, J. 2005. A correlation between Dynamic Cone Penetrometer values and pavement layer moduli, Geotechnical Testing Journal, 38(1).

[7] Webster, S. L., Grau, R. H., and Williams, T. P. 1992. Description and application of Dual Mass Dynamic Cone Penetrometer. Final Report, Department of Army, Waterways Experiment Station, Vicksberg, MS

[8] Livneh, M., Ishai, I., and Livneh, N. A. "Automated DCP Device versus Manual DCP Device." Road and Transport Research. Vol. 1, No. 4, 1992.

[9] Webster, S.L.; Brown, R.W.; and Porter, J.R. (1994). Force Projection Site Evaluation Using the Electric Cone Penetrometer (ECP) and the Dynamic Cone Penetrometer (DCP). Technical Report, GL - 94- 17, U.S Army Engineers Waterways Experiment Station. Vicksburg, USA.

[10] Ese, D., Myre, J., Noss, P., and Vxrnes, E. "The Use of Dynamic Cone Penetrometer (DCP) for Road Strengthening Design in Norway. Proceedings of the 4th International Conference on the Bearing Capacity of Roads and Airfields, pp.343-357, 1994

[11] National Cooperative Highway Research Program Transportation Research Board National Research Council (NCHRP) March 2001, Guide for Mechanistic-Empirical Design of new and rehabilitated pavement structures, correlation of CBR values with soil index properties. West University Avenue Champaign, Illinois USA.

[12] Afeez Adefemi BELLO, "Regression analysis between properties of subgrade lateritic soil," Leonardo Journal of Science, Issue 21, July-December 2012, pp. 99-108.

[13] Indian Road Congress "Guidelines for the Design of Flexible Pavements for Low Volume Rural Roads", IRC-SP-72-2007, The Indian Road Congress New Delhi, India.

[14] Amaranatha Reddy, M., Sudhakar Reddy, K. and Pandey B.B.(2001), 'Design CBR of Subgrade for Flexible Pavements', IRC Highway Research Bulletin No.64, June 2001 pp. 61-69.

[15] MORT\&H. 2013. "Specifications for Road and Bridge Works, 5th Revision", pp 75. Published By the Indian Roads Congress. New Delhi, India. 
[16] MORT\&H. 2013. "Specifications for Road and Bridge Works, 5th Revision", pp 428. Published By the Indian Roads Congress. New Delhi, India.

[17] Bureau of Indian Standards, "Determination of Dry Density of Soils In-Place, By the Sand Replacement Method" Is :2720 ( Part 28 ) 1974 ( Re-affirmed 1995 ), Bureau of Indian Standards, Manak Bhavan, 9 Bahadur Shah Zafar Marg, New Delhi

[18] Mohammad S. Pakbaz and Ali Siadati Moqaddam, "Effect of Sand Gradation on The Behavior of Sand-Clay Mixtures", Int. J. of GEOMATE, Sept., 2012, Vol. 3, No. 1 (Sl. No. 5), pp. 325-331, Geotec., Const. Mat. \& Env., ISSN:2186-2982(P), 2186-2990(O), Japan

[19] Mooney, M.A., Nocks, C.S., Selden, K.L., Bee, G.T., and Senseney, C.T. 2009. Improving Quality Assurance of MSE Wall and Bridge Approach Earthwork Compaction, Report No. CDOT-2008-11, Colorado Department of Transportation, Denver, Co, USA.

[20] AASHTO 2008. Mechanistic-Empirical Pavement Design Guide, July, 2008 Interim Edition. American Association of State Highway and Transportation Officials ASIN: B001P9MMBU, Washington DC.

[21] ASTM 2011. Standard Test Method for Measuring Deflections with a Light Weight Deflectometer (LWD), ASTM standard 2583 E-07.
[22] Vennapusa, P.P.K. and White, D. J., 2009. Comparison of Light Weight Deflectometer Measurements for Pavement Foundation Materials. Geotechnical Test Journal 32 (3): 1-13.

[23] Frost, M.W., Lambert, J.P., Fleming, P.R. 2007. A review of the Lightweight Deflectometer (LWD) for routine in-situ assessment of pavement material stiffness, Transportation Research Record 2004: Soil Mechanics 2007, pp.80-87, ISSN: 0361-1981. DOI: 10.3141/2004-09.

[24] Fleming P.R., Frost, M.W. and Lambert, J.P. 2009. Lightweight Deflectometers for quality assurance in road construction. IN: Tutumluer, E. and Al-Qadi, I.L. (eds). Bearing Capacity of Roads, Railways and Airfields: In Proceedings of the 8th International Conference (BCRRA), June 29 - July 2 2009, University of Illinois at Urbana Champaign, Illinois, USA, pp. 809-818. ISBN 9780415871990 .

[25] White, D., Thompson, M., and Vennapusa, P. 2007. Field Validation of Intelligent Compaction Monitoring Technology for Unbound Materials, Report No. 2007-10, Minnesota Department of Transportation, Saint Paul, MN, USA.

[26] IRC-SP. 2007. Guidelines for the Design of Flexible Pavements for Low Volume Rural Roads: IRC-SP-72. The Indian Road Congress New Delhi, India. Code of practice.

[27] ASTM. 2009. Standard Test Method for Use of the Dynamic Cone Penetrometer in Shallow Pavement Applications. ASTM standard D6951. 